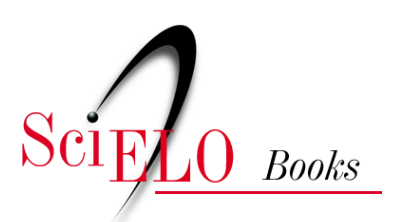

\title{
Pobreza e trabalho no Brasil
}

\author{
José Carlos da Exaltação Torres
}

\section{SciELO Books / SciELO Livros / SciELO Libros}

TORRES, J.C.E. Pobreza e trabalho no Brasil. In: Cadastro Único: tecnologia de reclassificação social [online]. Salvador: EDUFBA, 2016, pp. 63-79. ISBN: 978-65-5630-011-5. https://doi.org/10.7476/9786556300115.0006.

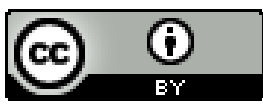

All the contents of this work, except where otherwise noted, is licensed under a Creative Commons Attribution 4.0 International license.

Todo o conteúdo deste trabalho, exceto quando houver ressalva, é publicado sob a licença Creative Commons Atribição 4.0. 


\section{POBREZA E TRABALHO NO BRASIL}

A emergência do trabalho livre no Brasil tem relação direta com a condição da pobreza. No momento em que Engels (1985, p. 97) utilizava a expressão "antiga escravatura" para referenciar as condições pioradas dos trabalhadores ingleses após a industrialização, no Brasil, aquelas mesmas condições se reproduziam sob (e por conta de) um ainda vigoroso sistema de escravidão. O “assassinato social” dos trabalhadores, descrito pelo pensador alemão, por sua submissão a condições indignas de subsistência, e exposição a todos os males que tais condições dão origem, no Brasil é dissimulado pela construção de uma imagem onde a situação vivida é tomada como atributo pessoal, característica inerente a um "tipo" de população. A construção da pobreza enquanto categoria social se dá vinculada ao seu histórico escravagista e recupera representações sociais estigmatizantes construídas a respeito do trabalho manual. Ou seja, a noção de pobreza reitera princípios excludentes através dos quais determinados grupos sociais foram alijados da participação ativa na vida socioeconômica do país, seja no caso dos "homens livres", considerados desocupados e vagabundos, dentre outros adjetivos de desqualificação social, seja o escravo, cuja condição não era sequer de homem, mas de coisa, e que após o Ato de Abolição, sob a pecha de "liberto", amargara uma exclusão concentrada, oriunda da associação de sua condição histórica com os filtros de absorção do mercado de trabalho capitalista. (IVO, 2008; NABUCO, 2003)

Joaquim Nabuco (2003), um dos nomes mais destacados na defesa da extinção da escravidão no Brasil, dirige sua crítica às elites nacionais do século XIX, em relação à contradição que representava a luta pela emancipação 
política do país com a manutenção do trabalho escravo e defende energicamente a bandeira do abolicionismo que, em suas palavras, "[...] começa pelo princípio, e, antes de discutir qual o melhor modo para um povo ser livre de governar-se a si mesmo [...] trata de tornar livre a esse povo". (NABU$\mathrm{CO}, 2003$, p. 33) Essa postura põe em destaque o fato de o povo brasileiro ter sido forjado nas malhas da escravidão, condição mantida ainda aos fins do século XIX, destoando do ritmo impresso a outros países que viveram situação semelhante e que tinham já no trabalho livre a referência de constituição das relações sociais.

Segundo a análise de Nabuco (2003), a Lei Rio Branco (Lei do Ventre Livre), aprovada no Brasil em 1871, estabeleceu limites à prática escravagista, mas simultaneamente reforçou o poder dos proprietários de escravos sobre estes. Estabeleceu mecanismos para os escravos comprarem a sua alforria, mas não criou as condições para que isso se efetivasse; criou um "fundo de emancipação", mas não lhe destinou os recursos necessários ao seu funcionamento; determinou a liberdade a todos os nascituros de escravos a partir daquela data (os quais seriam nominados por "ingênuos"), mas apenas a partir dos 21 anos de idade, até quando seriam mantidos em cativeiro. Em suma, o principal feito da lei foi amortecer o impacto da imagem de um Brasil escravagista diante de um mundo modernizado. Nabuco (2003) observa que a construção do discurso de governo após essa Lei lançava ao mundo a ideia de extinção gradual da escravidão no Brasil. Essa propaganda, porém, dissimulava as reais condições de vida da gente escravizada, o tratamento desumano que lhe era dispensado, a negação da liberdade à nova categoria social constituída, os "ingênuos". Tudo se omitia. Segundo o autor, depois da Lei "a vida dos escravos não mudou nada”. (NABUCO, 2003, p. 115)

E Nabuco vai mais além. Segundo sua interpretação, de uma forma geral, a obra da escravidão foi a devastação do território no qual se desenvolveu e a condenação à miséria da população posta ao seu serviço. Uma cultura de privilégios e extravagâncias dos exploradores coloniais exauriu a terra e a vida das pessoas, "[...] o resultado final daquele sistema é a pobreza e a miséria do país”. (NABUCO, 2003, p. 137) As províncias dividiam-se em grandes latifúndios, isolados da vida exterior, sob o domínio da vontade senhorial, à qual se submete até a população "livre" local. A escravidão criou cidades, nas palavras de Nabuco, "mortas", "decadentes”. A centralização comercial nas capitais levou à inanição do interior. "Tome-se o Cabo, ou Valença, ou qualquer outra cidade do interior de qualquer província, e há de ver-se que 
não tem vida própria, que não preenche função alguma definitiva na economia social". (NABUCO, 2003, p. 139) Isto porque a aristocracia rural não apresentava interesse em fazer desenvolver o campo. O que se extraía da terra, em riquezas, por exploração do trabalho escravo, desbastava-se nos centros urbanos; um arremedo de modernização subordinada a formas de dominação conservadoras.

A decadência gerada pela escravidão se observa de forma mais sensível em fins do século XIX, nas condições de vida da população rural, a exemplo de suas habitações improvisadas, as quais não dispunham sequer de dormitórios.

As habitações [...] são quatro paredes, separadas no interior por uma divisão em dois ou três cubículos infectos, baixas e esburacadas, abertas à chuva e ao vento, pouco mais do que o curral, menos do que a estrebaria. É nesses ranchos que vivem famílias de cidadãos brasileiros! A alimentação corresponde à independência de hábitos sedentários causada pelas moradas. É a farinha de mandioca que forma a base da alimentação, na qual entra, como artigo de luxo, o bacalhau da Noruega ou o charque do Rio da Prata. (NABUCO, 2003, p. 147-148)

Em que difere tal descrição daquela feita por Engels (1985) sobre a Inglaterra, naquele mesmo século, algumas décadas antes? Talvez apenas no fato de num contexto ela estar vinculada ao trabalho livre e noutro à negação desse tipo de trabalho. A escravidão no Brasil produziu fileiras de pessoas sobrevivendo nos limites mínimos de subsistência, impedidas reiteradas vezes de alcançar a condição de cidadania, de acessar direitos básicos de sobrevivência.

\section{A CONSTRUÇÃO DE UMA NOVA ORDEM ORIENTADA PELOS CRITÉRIOS DIFERENCIADORES DA SOCIEDADE COLONIAL}

É dessa perspectiva que Anete Ivo (2008) analisa a forma pela qual a sociedade colonial negava aos "homens livres" um estatuto social, verificando que a posição social daquelas pessoas não se enquadrava nos papéis definidos pela ordem escravocrata, e a forma encontrada para repelir a existência dessa categoria destoante foi sempre a desqualificação social, associando a condição de "livre" a adjetivos estigmatizantes, como "incapaz", "vadio", "desocupado", "vagabundo”. Associado e amparado nisto, havia 
um esforço para a construção de um aparato legal à obrigatoriedade do trabalho e imposição de sanções contra essas pessoas. (IVO, 2008, p. 113) Essa "herança colonial" impôs um "efeito de naturalização", semelhante ao que analisou Bourdieu (1997), referindo-se às lutas sociais de classificação, sobre os destinos da população pobre brasileira, tal qual noutros contextos o fizera o trabalho livre.

A ideologia colonial sempre procurou justificar esse processo de formação de grandes maiorias 'desocupadas' por diversas 'teorias' que naturalizavam o processo de exclusão social como inferioridade racial, fatalismo histórico, rigor do clima tropical e várias outras 'causas naturais' e inerentes a esses indivíduos e sociedades. (IVO, 2008, p. 116)

Foi também em razão do passado colonial que Florestan Fernandes (1981) analisou o processo de implantação de uma "ordem social competitiva" no Brasil. Para esse autor, países de origem colonial absorvem o capitalismo sem a criação imediata de uma ordem social que lhe corresponda, promovendo um ajuste às estruturas política, econômica e social existentes. Desta forma, as estruturas tradicionais determinam a natureza das relações que se desenvolvem com o mercado mundial, característico do capitalismo. No Brasil, essas estruturas retardaram a expansão nacional do sistema capitalista, exercendo controle político sobre a dinâmica de importação e exportação, que economicamente submetia-se ao controle externo.

O fundamento desse fenômeno não está necessariamente na condição de colônia, mas no tipo de sociedade desenvolvida a partir dela. A emancipação política brasileira, conquistada no processo de Independência, não alterou a ordem social estabelecida, ao contrário, fortaleceu-a. Nas palavras de Fernandes (1981, p. 162), "só sob a emancipação política a ordem social de castas e estamentos, herdada da Colônia, iria concretizar suas potencialidades de diferenciação e de desenvolvimento". O poder concentrado nas mãos da aristocracia agrária permitiu a essa classe determinar o ritmo em que as transformações, que vinham na cauda do novo status político do país, se dariam, de modo a não alterar seus níveis de privilégios e o seu prestígio no conjunto da sociedade. Dessa forma, a competição, característica fundamental para o desenvolvimento da ordem capitalista, serviu de mecanismo de reiteração das distinções sociais da ordem tradicional. Como não se podia controlar a dinâmica do mercado mundial, controlavam-se seus efeitos na dinâmica econômica interna. A competição servia, portanto, à elaboração 
de um modelo específico de ordem competitiva. A ordem senhorial "convertia a 'livre iniciativa' e a 'empresa privada' em privilégios estamentais, que deviam ser respeitados e protegidos fora e acima de qualquer racionalidade inerente aos processos econômicos propriamente ditos". (FERNANDES, 1981, p. 156)

Os estamentos intermediários, reconhecidos socialmente como senhoriais, mas que não gozavam efetivamente dos mesmos privilégios das camadas superiores, agiam de forma semelhante, mas por outras vias. Na nova ordem política, os membros desses estamentos ocupavam cargos que lhes dispunham o exercício do poder em determinados graus, e utilizavam-se dessa condição para garantir distinção em relação às camadas que lhes eram inferiores e cuja aquisição da condição nobiliárquica poderia se lhes igualar.

[...] sob vários subterfúgios, a modernização da legislação, da política e da administração preenchia, de fato, a função latente de compensar a perda relativa de prestígio social, através do desnivelamento dos prestígios econômicos, sociais e políticos. Daí surgiram inovações úteis e aparentemente 'democráticas' (principalmente nas esferas em que esses estamentos transferiam para a coletividade o ônus do financiamento, que não podiam enfrentar, do seu próprio status, com medidas pertinentes à gratuidade do ensino e outras garantias sociais, às quais dificilmente a plebe teria acesso). (FERNANDES, 1981, p. 160)

Esses elementos representavam tensões na base da ordem estamental, mas o estopim para a sua desagregação estava no que Florestan Fernandes (1981) chamou de "conflito axiológico". Embora a distribuição dos papéis sociais girasse em torno da condição senhorial, a emancipação política do país estava contradita à condição servil de seu povo. Os valores ideais, voltados à constituição de uma sociedade nacional, contrapunham-se àqueles que orientavam a prática, gerando "inconsistências [...] em torno do status de cidadão” (FERNANDES, 1981, p. 162), porque a “ordem legal” excluía escravos, libertos e "homens livres". A escravidão "[...] feria, ao mesmo tempo, os mores religiosos, os 'foros de povo civilizado' e os requisitos ideais da ordem legal, além de sua supressão contar como o fundamento econômico perfeitamente visível da expansão ulterior do capitalismo". (FERNANDES, 1981, p. 163, grifo do autor) Para esse autor, o movimento social que se formou em favor do abolicionismo tinha na modernização econômica a sua principal meta, não necessariamente a emancipação da população escravi- 
zada ou a destituição dos privilégios das classes dominantes, inclusive porque seus defensores eram radicados nessas classes.

O caráter revolucionário que o abolicionismo alcançou foi, neste sentido, um acontecimento acidental, "inesperado". Sua formulação estava na esfera das relações de interesses "entre iguais", como elemento de competição dentro da ordem vigente; "os alvos sociais visados tinham em vista aumentar a elasticidade da ordem social vigente, adaptando-a aos requisitos materiais e formais do capitalismo" (FERNANDES, 1981, p. 164), jamais à alteração da condição social do escravo. ${ }^{11}$ Assim, embora seu uso tenha objetivado sempre a manutenção da ordem, as inconsistências e tensões dessa ordem permitiram, à competição, subvertê-la.

Ao crescer, ela [a competição] iria não só operar como uma força social incompatível com o equilíbrio e a perpetuação da ordem escravocrata e senhorial. Ela iria também revelar-se como uma influência sociodinâmica incontrolável, que solapava os critérios estamentais de atribuição de status e papéis sociais, de solidariedade econômica ou política etc., acelerando o ritmo da desagregação dos estamentos dominantes. (FERNANDES, 1981, p. 166)

Uma ordem estamental num ambiente liberal é fator de tensões e inconsistências essencialmente incontornáveis, principalmente pela influência de elementos externos sobre a cultura doméstica. A competição é um elemento eminentemente capitalista e, por isso, o seu uso, por melhor articulado que esteja às estruturas tradicionais, compele-as à mudança, principalmente se estiver em contradição com a formação da estrutura de classes que caracteriza o capitalismo. A atribuição de status social com base na origem dos indivíduos não se coaduna com a atribuição de papéis a partir das relações sociais de produção. Mas a ordem senhorial assimilou bem a competição, que ficou, assim, "associada [...] aos interesses, valores sociais, e estilo de vida dos estamentos privilegiados e dominantes”. (FERNANDES, 1981, p. 167) Essa deformação do elemento competitivo se refletiria sobre a nova ordem social com a manutenção de aspectos arcaicos e o retardamento

11 Ao que nos parece, a obra de Joaquim Nabuco aqui referida, O abolicionismo, desautoriza a generalização das conclusões de Florestan Fernandes (1981, p. 163) quanto ao caráter restritivo do abolicionismo, ainda que este autor cite explicitamente a consternação do "próprio Nabuco", que era, em suas palavras, "o maior paladino do pensamento liberal em toda a história brasileira". 
do desenvolvimento dos aspectos modernos. "O horizonte cultural orienta o comportamento econômico capitalista mais para a realização do privilégio (ao velho estilo), que para a conquista de um poder econômico, social e político autônomo". (FERNANDES, 1981, p. 167)

De toda forma, se a implementação do capitalismo no Brasil foi retardada, a construção da pobreza e da miséria se antecipou, como se pôde verificar nas análises de Joaquim Nabuco citadas acima, e cuja referência é de um período antes mesmo de se dar a Abolição. Talvez isto tenha se dado como o resultado nefasto da combinação de caracteres excludentes de duas formas distintas de organização social, de um lado, uma ordem social estamental, e de outro, elementos de uma "ordem social competitiva", que custou a se completar. E nisso se observa o quanto a revolução burguesa descrita por Marx e Engels (1999), no Manifesto Comunista, como inexorável a todas as nações, pode ser ainda mais danosa às relações sociais, se combinada a elementos de diferenciação estranhos ao capitalismo, mas igualmente excludentes. Ao que se pode perceber, esses elementos desenvolvem a capacidade de se potencializar mutuamente. Como analisa Fernandes (1981, p. 168), a competição no Brasil criou “[...] uma ordem social em que, além da desigualdade das classes, conta poderosamente o privilegiamento dos privilegiados na universalização da competição como relação e processo sociais”.

É verdade que a emancipação política do país semeou em seu território o germe de uma sociedade moderna, mas paradoxalmente reiterou a organização social vigente, porque consolidou o poder nas mãos das elites nacionais, dos estamentos senhoriais, que não abdicariam de suas posições privilegiadas em favor da construção de uma nova ordem social, onde a competição orientaria os critérios definidores das posições sociais. Isso se exemplifica na Constituição do Império, de 1824, onde se sustentam princípios liberais, enunciando a construção dos direitos civis e, portanto, de um dos pilares da cidadania no país. Mas a sociedade de então era tida em termos semelhantes aos colocados por Engels (1985, p. 153) sobre a Inglaterra do século XIX, referia-se à "classe que [...] possui o poder político e social”. Como afirma Couto (2006, p. 86), "O modo como foram incorporadas, na vida concreta dos brasileiros, as regras constitucionais de 1824 representa uma particularidade de uma sociedade com características autoritárias e conservadoras". Constituiu-se uma "nova” sociedade, da qual se excluía o povo. Se a Constituição engendrava direitos, era em referência às próprias classes que os conceberam. 


\section{O LUGAR DOS POBRES NA CIDADANIA BRASILEIRA}

Alterações relativamente significativas na estrutura social brasileira se verificaram principalmente a partir da década de 1930, com a implantação do processo de industrialização do país. Mas o ritmo das mudanças também obedeceu, em determinados aspectos, ao receituário histórico. A esse respeito, Ivo (2008, p. 123) considera que, no que tange às representações sobre o trabalho, a "ideologia colonial" vigorou "até o período da $2^{\underline{a}} \mathrm{Gran}-$ de Guerra", ainda que tenha sofrido modificações, dadas pela admissão de "novas regulações do trabalho" (IVO, 2008, p. 121) a partir dos processos de abolição da escravatura e proclamação da república, além da influência da imigração estrangeira no país.

Um exemplo significativo da manutenção de certos aspectos dessa ideologia, mesmo já na república, pode ser encontrado nas análises feitas por Licia Valladares (2000) sobre o processo de construção social das favelas do Rio de Janeiro, num contexto em que esta cidade figurava ainda como Distrito Federal do Brasil. A autora demonstra como as representações negativas construídas ao longo do século XIX, sobre as habitações populares, concentradas na figura do cortiço, tido este "como o locus da pobreza", "como antro não apenas da vagabundagem e do crime, mas também das epidemias, constituindo uma ameaça às ordens moral e social” (VALLADARES, 200o, p. 7), legitimaram a ação governamental na desarticulação dessas habitações, já nos primeiros anos do século XX. A pobreza continuava, portanto, associada à vadiagem, ao desinteresse pessoal por uma atividade produtiva. Responsabilidade depositada sobre o indivíduo, culpabilizado por sua "má sorte". Tal medida compeliu parcelas da população pobre a se abrigar nos morros e incrementar as ocupações iniciadas já em fins do século anterior e que dariam origem às favelas cariocas.

Valladares (2000) observa, contudo, que o uso dessa nova categoria designativa das "aglomerações pobres" (ainda associadas à vadiagem e à desocupação) se expressa a partir da segunda década do século XX; "para ela [a favela] se transfere a visão de que seus moradores são responsáveis pela sua própria sorte e também pelos males da cidade”. (VALLADARES, 2000, p. 8) Analisando a forma como a imprensa da época divulgava as impressões de seus observadores sobre a favela, a autora conclui, com recurso a uma citação de Luiz Edmundo (1938, p. 252), que 
Começava a se impor a idéia da favela não apenas como espaço inusitado, desordenado e improvisado, mas também como reduto da pobreza extrema, onde vivem 'mendigos [...], capoeiras, malandros, vagabundos de toda sorte, mulheres sem arrimo de parentes, velhos dos que já não podem mais trabalhar, crianças, enjeitados em meio a gente válida [...], sem ajuda de trabalho, verdadeiros desprezados da sorte [...]'.

E é na década de 1930 que a favela, tomada como um problema social, começa também a ser enfrentada pelo Poder Público, fato expresso no "Código de obras" de 1937, onde ela aparece classificada na seção de "habitações anti-higiênicas" a serem extintas. "Foi certamente a necessidade de administrar a favela e os seus pobres que despertou o interesse em conhecê-la e conhecê-los mais de perto". (VALLADARES, 200o, p. 19) O enfrentamento do problema demandava, portanto, conhecimentos objetivos sobre aquela realidade. A década de 1940, segundo a autora, destacou-se no processo de construção desse conhecimento. Já em 1941, fora publicado o relatório de um "levantamento", de autoria particular de um médico, realizado especificamente sobre as favelas, oferecendo informações detalhadas sobre os seus habitantes e suas respectivas habitações (VALLADARES, 2000); em 1942, publicou-se o primeiro livro sobre o tema, resultante de um estudo de caso para conclusão de curso em Serviço Social, sobre uma favela específica, o "Largo da Memória”. Do trabalho em voga, Valladares (2000) destaca um trecho onde se assimila o "pobre" ao "liberto" e reitera-se a sua associação com a vadiagem, como sendo uma característica pessoal e cuja superação demanda o auxílio do Estado:

Filho de uma raça castigada, o nosso negro, malandro de hoje, traz sobre os ombros uma herança mórbida por demais pesada para que a sacuda sem auxílio, vivendo no mesmo ambiente de miséria e privações; não é sua culpa se antes dele os seus padeceram na senzala, e curaram suas moléstias com rezas e mandingas. [...] É de espantar, portanto, que prefira sentar-se na soleira da porta, cantando, ou cismando, em vez de ter energia para vencer a inércia que o prende, a indolência que o domina, e resolutamente pôr-se a trabalhar? [...] Para que ele o consiga, é preciso antes de mais nada curá-lo, educá-lo, e, sobretudo, dar-lhe uma casa onde o espere um mínimo de conforto indispensável ao desenvolvimento normal da vida. (SILVA, 1942, p. 62-63 apud VALLADARES, 200o, p. 22)

Esse fato é bastante significativo, considerando-se, como faz Licia Valladares (2000, p. 21), que "de certo modo, as assistentes sociais funcionavam como a mão direita da administração municipal na gestão da pobreza: 
entre a proteção social e o controle dos pobres". A atuação das assistentes sociais foi, assim, fundamental na construção do conhecimento sobre a favela, por conta de seu acesso facilitado às famílias pobres.

Afora esses estudos, os dados oficiais foram produzidos ao fim da década. O primeiro censo específico das favelas do Rio de Janeiro foi realizado pela Prefeitura local entre 1947 e 1948, tendo seus resultados publicados em 1949, onde se identificava a existência de 105 favelas e mais de $138 \mathrm{mil}$ habitantes, ou $7 \%$ da população do então Distrito Federal, distribuídos em pouco mais de 34,5 mil residências, cada uma contendo em média quatro moradores. (VALLADARES, 200o, p. 23) Posta a importância do problema, o Censo Demográfico nacional de 1950 contemplou uma investigação suplementar sobre a população das favelas do Rio.

Voltando à referência à década de 1930, período deflagrador da industrialização no Brasil, Edson Nunes (1997) analisa o processo de implantação do capitalismo no país, no qual vai identificar a persistência de valores e práticas condizentes com a antiga ordem social. Para esse autor, países de industrialização recente, como o Brasil, precisam criar instituições compatíveis com a nova ordem econômica, a qual se torna preponderante também na organização da vida política e social. Mas, como que reiterando a persistência de uma herança histórica, Nunes (1997) ressalta o papel que as instituições políticas desempenharam na construção das relações de classe e no estabelecimento de padrões de acumulação no país, com a manutenção de elementos da ordem social tradicional. O autor considera que a criação das instituições exigidas pela nova ordem econômica não se deu obedecendo estritamente à racionalidade de mercado, mas à articulação entre quatro distintas "gramáticas políticas": clientelismo, corporativismo, insulamento burocrático e universalismo de procedimentos.

O clientelismo figura como o tipo de gramática política que perpassa toda a história do país, resultado provável da estrutura social construída com base na sociedade senhorial, como, aliás, analisou Nabuco (2003), onde a subordinação à vontade soberana dos aristocratas era uma conduta social generalizada. O corporativismo, por sua vez, foi adotado a partir do Governo Vargas, e serviu como importante mecanismo estatal de controle político sobre os trabalhadores urbanos. O universalismo de procedimentos foi adotado como forma de infundir lisura na formação dos quadros do funcionalismo público, enquanto que o insulamento burocrático visava resguardar os núcleos técnico-burocráticos do governo das ingerências e 
disputas políticas. Como que indiferente a essas medidas, e mesmo articulado a elas, o clientelismo se manteve e, com a centralização do poder no Governo Federal, a sua operação, antes tática política das oligarquias locais, ganha também foro nacional.

Decerto, a utilização dessas políticas compunha o conjunto de manobras que permitiu às oligarquias manterem a sua posição social, mesmo após o estabelecimento de um regime de classes no país. Florestan Fernandes (1981) observa que, em razão da dispersão dos grupos representantes dos interesses burgueses no Brasil, a dominação burguesa se realizou a partir do plano político, com o Estado atendendo a demandas particularistas. Ou seja, a frouxidão com que se articulavam as frações burguesas, aproximadas estritamente no âmbito comercial, encontra assento no Estado; antes da dominação econômica e social opera-se, portanto, uma dominação política.

No trânsito lento que levou o Brasil Império à modernidade, a aristocracia mudou-se em oligarquia e fundiu-se posterior e como que aditivamente à burguesia. Do Império à República, operou-se uma "recomposição das estruturas de poder" (FERNANDES, 1981, p. 203) a caminho da configuração da classe burguesa. Após a abolição, a aristocracia precisava se renovar para manter sua hegemonia, precisava recompor sua dominação em função dos novos princípios de ordenação social. Essa "recomposição" do poder oligárquico em torno das estruturas do Estado republicano caracteriza a construção da era moderna no Brasil, onde a redefinição dos papéis sociais, reclamada pela nova ordem, não modificou a estrutura de distribuição de poder, a posição dos agentes no espaço social. A passagem de uma "era" a outra se faz sem transformações profundas. A burguesia brasileira tinha na modernização uma referência instrumental, não a alteração de uma ordem social a novos padrões de convivência, mas a absorção de um modelo produtivo que aperfeiçoasse as vantagens materiais que pudesse acessar.

O Estado republicano, assim, não significou uma ruptura nos arranjos de poder da velha ordem. Em verdade, ele solucionaria o problema da liberalização da mão de obra, criando as condições para a recomposição do poder da antiga aristocracia. O elemento burguês não desponta como a negação do modo de vida senhorial, no sentido da supressão de privilégios de grupos específicos. Ele fazia parte daquele mundo e queria reordená-lo a partir de uma nova base de poder, mas sem alterar seus parâmetros de dis- 
tribuição. A “lógica da dominação burguesa” (FERNANDES, 1981, p. 210) referenciava-se mesmo nas oligarquias.

Se as tensões geradas por esse arranjo ameaçavam a dominação burguesa, esta soube revertê-las em vantagens para o seu êxito. E como a formação das camadas proletárias despontava como principal empecilho, será contra a mobilização dos trabalhadores que se despenderá maior força. O liberto, que ameaçava a ordem espacial antiga, volta à cena na condição de trabalhador assalariado, ameaçando o poder reformulado, diante de uma classe burguesa "ultraconservadora e reacionária” (FERNANDES, 1981, p. 213), afinada com os princípios de um capitalismo dependente.

[...] a burguesia atinge sua maturidade e, ao mesmo tempo, sua plenitude de poder, sob a irrupção do capitalismo monopolista, mantidas e agravadas as demais condições, que tornaram a sociedade brasileira potencialmente explosiva, com o recrudescimento inevitável da dominação externa, da desigualdade social e do subdesenvolvimento. (FERNANDES, 1981, p. 220)

Esses são elementos imprescindíveis para a compreensão do processo de construção da cidadania na sociedade brasileira e do caráter restritivo que a orientou, com uma limitada margem de inclusão. A forma como se desenvolveu esta sociedade, pautada em valores particularistas e onde a condição cidadã funcionava muito mais como privilégio que como direito, construiu um sistema modelar de desigualdade social diante do mundo, cuja resolução se tornou um dos principais desafios para os governantes nacionais em toda a história republicana. Isso polemiza o debate sobre a existência ou não de um Welfare State no Brasil, o que não impede que alguns autores admitam, e até sem muitas reservas, a concepção de um regime de bem-estar desde a década de 1930. É o que se verifica, por exemplo, na discussão desenvolvida por Marcelo Medeiros (2001, p. 6), para quem o Welfare State dá conta de uma "mobilização em larga escala do aparelho de Estado em uma sociedade capitalista a fim de executar medidas orientadas diretamente ao bem-estar de sua população”. As considerações de Medeiros refletem determinadas contradições, cuja análise pode levar à negação de sua própria tese, contudo, importa ressaltar que o autor põe em evidência o caráter restritivo e eminentemente político da proteção social engendrada pelo Estado brasileiro.

Num recurso a Malloy (1979), Medeiros (2001, p. 11) afirma que "a década de 1930 é caracterizada pela estratégia deliberada de aumentar o papel 
do Estado na regulação da economia e da política nacionais como estratégia de desenvolvimento", apoiado na desmobilização e cooptação dos trabalhadores, cuja relação com o Estado combinava também o patrimonialismo e o corporativismo, o que se exprime no "esquema de proteção social criado para atender aos setores organizados da classe trabalhadora urbana fundamentado no sistema de previdência social”. (MEDEIROS, 2001, p. 11)

Ao favorecer o fenômeno do corporativismo, a estrutura de seguridade criada teve o papel de minar a possibilidade de a classe trabalhadora organizar um movimento de oposição autônomo ao regime de capitalismo regulado pelo Estado. A previdência social contribuiu para a criação de divisões na classe trabalhadora e incentivou entre os trabalhadores uma mentalidade particularista e essencialmente depende[nte] do clientelismo do Estado. O sistema contribuiu para a incorporação de importantes segmentos da classe trabalhadora no conjunto de estruturas corporativistas, o que aumentou, em princípio, o poder regulatório do Estado patrimonialista. (MEDEIROS, 2001, p. 11-12)

O autor quer demonstrar com isso o grau de comprometimento da esfera burocrática com os interesses do governo, o que minava, segundo a sua interpretação, a possibilidade de desenvolvimento de um Welfare State de caráter redistributivo, que dependia de coalizões políticas entre os trabalhadores, principalmente os funcionários públicos, ou seja, a proeminência dos interesses de classe, expressos na reivindicação da progressividade dos gastos sociais sobre os interesses corporativistas particulares. "Como a institucionalização do Welfare State no Brasil teve como meta a regulação da força de trabalho em uma indústria de dimensões limitadas, apenas os grupos pertencentes ao núcleo capitalista da economia fizeram parte do compromisso”. (MEDEIROS, 2001, p. 12, grifo nosso) O próprio Medeiros (2001) demonstra, portanto, que a pretensa institucionalização de um Welfare State não tinha como fim o bem-estar da população, mas o propósito do desenvolvimento industrial do país; servia de estratégia política para cimentação das bases para o desenvolvimento. ${ }^{12}$ Essa característica teria sido mantida mesmo após a restauração da democracia, em 1945. O autor afirma

12 Isso compromete, inclusive, o conceito adotado pelo autor, porque o Welfare State brasileiro seria mais uma contrafação de um modelo desenvolvido no Norte que uma vertente do mesmo. Não há, diante do exposto, uma preocupação com as desigualdades; ao contrário, criam-se condições para que elas possam se acumular sem contestação social, sem que ameacem o desenvolvimento econômico. 
que, mantido também o caráter populista dos governos, houve estímulo “à mobilização das massas urbanas em torno dos projetos da burguesia industrial” (MEDEIROS, 2001, p. 13), o que permitiu avanços nas conquistas dos trabalhadores, conformadas nas alterações da legislação trabalhista, mas de extensão ainda limitada a determinados segmentos. A seletividade inerente aos esquemas de proteção existentes beneficiava grupos específicos, notadamente pelo caráter contributivo da concessão de benefícios. Todo o período de criação da base institucional do Welfare State brasileiro, que vai da década de 1930 ao início da década de 1960, é marcado, então, por políticas sociais de caráter populista e, sobretudo, limitadas em seus alcances, porque condicionadas aos interesses corporativistas e voltadas sobremaneira ao desenvolvimento industrial do país.

Essa perspectiva pode ser posta em diálogo com a análise que faz Berenice Couto (2006) sobre direito e assistência social no Brasil, porque demonstra o matiz exclusivista da criação dos direitos sociais no país. Medeiros (2001) refere-se eminentemente ao período compreendido entre $1930 \mathrm{e}$ 1960, intervalo no qual, segundo Couto (2006), as políticas sociais no Brasil condicionaram-se determinantemente ao ideal de desenvolvimento e crescimento econômicos do país, não demonstrando qualquer preocupação com as populações excluídas desse processo, notadamente os trabalhadores do campo, o que sugere o comprometimento do governo com as oligarquias rurais que se mantiveram, como disse Fernandes (1981), na condição de agente econômico privilegiado.

Em 1930 o Brasil tinha já uma relação com o mercado internacional maturada em certo grau, correspondendo à condição de uma economia competitiva dependente. Nestes termos, a crise econômica deflagrada nos Estados Unidos em 1929 tivera consequências também no território brasileiro. Considera-se, assim, que é o quadro de desconforto econômico-social generalizado que dá o mote para a Revolução de 1930. Couto (2006) observa que, à época, registrava-se, dentre outros problemas, maior precarização das condições de vida da população e elevação do desemprego. Embora o governo tenha, num primeiro momento, rompido com as oligarquias até então dominantes, recuou posteriormente, restabelecendo um pacto pela governabilidade. Ressalta-se, porém, que este é um novo momento, porque aí se introduzem novos atores, figurados nas classes médias urbanas.

A legislação desse período constitui um marco para a consolidação da democracia no país, mas como visava sobretudo distensionar as vias para o 
desenvolvimento econômico do país, assumiu caráter francamente restritivo, contemplando apenas os trabalhadores dos setores produtivos urbanos, não alcançando o trabalho no campo ou a massa desempregada. Tanto no âmbito das relações trabalhistas quanto na instituição de sistemas previdenciários, o Estado atuou no aporte de proteção social.

Foi o emprego assalariado, portanto, que constituiu a via de acesso aos direitos sociais, o mecanismo de inclusão social por excelência, de participação na vida coletiva, fato consolidado na Constituição de 1934. A partir do Golpe de Estado, em 1937, aumentou o controle do Estado sobre os trabalhadores e, por correspondência, sobre o exercício dos direitos, os quais se submeteram a efeitos suspensivos, em favor do projeto de desenvolvimento encampado pelo governo. Criou-se um invólucro protetor ao aparelho do Estado, prevenindo qualquer perturbação à realização de sua obra transformadora, a qual permitiu, em razão de seus fins, a adoção de políticas educacionais e de formação profissional que alcançavam também as classes até então excluídas. "A ditadura Vargas (1937-45) voltou sua atenção para o controle da classe trabalhadora, utilizando como recurso a legislação social fortemente centrada no controle estatal”. (COUTO, 2006, p. 102)

De acordo com essa análise, a deposição do governo para a redemocratização do país, ocorrida em 1945, não alterou o caráter de condução das políticas sociais, exceto pelo fato de distender em algum grau o seu controle. Mas toda orientação seguia no sentido de fortalecer ou sustentar a industrialização. Segundo Couto (2006), o primeiro plano governamental a contemplar a questão social no Brasil é de 1948, o "Plano Salte”, com parcos efeitos práticos, por contar com baixos investimentos para este setor. Quanto à relação com os trabalhadores, o governo "democrático" agiu repressivamente, tosando toda mobilização da classe. Essa situação se reverteu com a volta de Vargas ao poder, em 1951, que recuperou a sua tática de negociação com a classe trabalhadora. Mas, ainda segundo essa análise, o clima efervescente do período, com atuação firme dos sindicatos, levou também aquele governo a imprimir um tom repressivo contra os trabalhadores.

O governo Juscelino Kubitschek (JK), primeiro presidente eleito após a morte de Getúlio Vargas, estabeleceu um “Plano de Metas”, composto também por programas sociais, os quais subsumiram ante a persistente meta principal de desenvolvimento econômico, alcançada às custas da elevação do desemprego, da exclusão social, da inflação e da defasagem salarial. No âmbito dos direitos, Couto (2006) destaca do período JK, a aprovação da 
Lei Orgânica da Previdência Social (LOPS), que promoveu a centralização da gestão e a universalização da Previdência. Já no governo de João Goulart, sucessor do renunciante Jânio Quadros, a classe trabalhadora realizou conquistas importantes, como o $13^{\circ}$ salário e o salário família. Mas, ainda com o fato destacado de a proteção social mais uma vez não alcançar os trabalhadores rurais, que representavam, paradoxalmente, a maior parte da População Economicamente Ativa (PEA) no período. A postura aberta do governo Goulart para negociação com os trabalhadores, o aumento das manifestações populares contra a degradação das condições de vida e a insinuada reforma social foram fatores que despertaram a reação dos grupos contrários a esse quadro, o que levaria à destituição do governo e à instauração de uma ditadura militar no país.

Assim, todo o intento, desde a década de 1930, para harmonizar as relações entre as classes não alcançou tal fim, decerto porque o fazia mediante controle sobre os trabalhadores. O incremento constante das desigualdades sociais tornara explícitas as contradições do sistema adotado, e os avanços da classe trabalhadora na conquista de direitos eram um indício de que as classes dominantes perdiam terreno e, em seu rastro, o sistema inteiro. O Golpe Militar de 1964 veio abolir a ameaça e tonificar o projeto de desenvolvimento e crescimento do país em caráter autoritário.

Sob um apelo nacionalista, o Estado tentava moldar uma atmosfera de resignação da população em relação às suas precárias condições de vida e à postura sumamente repressora dos governos no período militar. Os militares promoveram um ataque aberto aos direitos políticos e civis, dissolvendo-os paulatinamente, através de Atos crescentemente coercitivos. Os direitos eram cerceados, concedidos apenas a quem "se [submetesse] às regras instituídas pelo governo militar”. (COUTO, 2006, p. 123) Dessa perspectiva, direitos e cidadania tornaram-se coisas distintas, postas na contramão uma da outra. Teria direito quem abrisse mão do exercício da cidadania. ${ }^{13}$ Couto (2006) reconhece a existência de alguns avanços na área social com a extensão das políticas aos trabalhadores rurais, autônomos e domésticos. Destaca-se também a adoção de políticas habitacionais (com a ressalva de

13 Como se viu acima, é dessa mesma perspectiva que Marshall (1967, p. 172) analisa o surgimento dos direitos sociais na Inglaterra do século XIX, quando os direitos concedidos, a exemplo dos abonos da Speenhamland Law, estavam desvinculados da condição de cidadania, concedidos a quem deixasse "inteiramente de ser cidadão". 
que sua implementação beneficiou majoritariamente a classe média, por conta dos custos de financiamento); a criação do Ministério da Previdência e Assistência Social (MPAS), em 1974 e, em 1979, quando se instituiu o Sistema Nacional de Previdência e Assistência Social (SINPAS), vinculando as instituições responsáveis pela gestão de benefícios previdenciários e assistenciais; do mesmo período é também a criação da Renda Mensal Vitalícia (RMV), substituída, na década de 1990, pelo Benefício de Prestação Continuada (BPC), através da Lei 8.742/93, Lei Orgânica da Assistência Social (LOAS).

Se, por um lado, a medida teve seu aspecto favorável, pois a unificação dos benefícios e recursos poderia racionalizar e deixar mais transparentes a oferta e o gasto das políticas, por outro, ao realizá-la, os governos da ditadura militar efetivaram seus propósitos de controlar a oferta dos benefícios e, automaticamente, controlar a população, que, em última instância, era quem financiava os próprios benefícios ofertados pela política previdenciária, mas que, em virtude do processo conjuntural repressor, não era assim compreendido pala maioria da população. (COUTO, 2006, p. 131-132)

Assim, todas essas mudanças se condicionavam aos mesmos princípios de controle com vistas ao desenvolvimento. Às mazelas sociais, restava a metáfora do "bolo", ${ }^{14}$ que cresceu, fermentado pela anulação dos direitos e emulação das desigualdades, e jamais foi repartido.

14 Referência à teoria desenvolvimentista na qual o crescimento econômico exige priorização dos investimentos em industrialização, postergando o desenvolvimento social, metaforicamente, sendo necessário deixar o bolo crescer para depois dividi-lo. 